\title{
Changes in Subtidal Community Structure Associated with British Columbia Sea Otter Transplants*
}

\author{
Paul A. Breen ${ }^{1}$, Trudy A. Carson ${ }^{2}$, J. Bristol Foster ${ }^{2}$ and E. Anne Stewart ${ }^{3}$ \\ ${ }^{1}$ Department of Fisheries and Oceans, Resource Services Branch, Pacific Biological Station, Nanaimo, British Columbia \\ V9R 5K6, Canada \\ ${ }^{2}$ Ecological Reserves Unit, Ministry of Lands, Parks \& Housing, Victoria, British Columbia, Canada \\ ${ }^{3}$ Box 26, Bamfield, British Columbia, Canada
}

\begin{abstract}
Sea otters Enhydra lutris were re-introduced into coastal waters of British Columbia, Canada, in 1969-1972, after being hunted to extinction in the previous 2 centuries. In 1979, we visited an area where 55 individuals had been seen in 1978, and we made subtidal observations of the abundance and distribution of red sea urchins, other grazers, and kelps. Earlier observations, made in the area before sea otters were re-introduced, confirmed that changes have taken place in subtidal communities since the re-introduction. Where sea otters had been observed feeding, sea urchins Strongylocentrotus franciscanus were scarce and restricted to crevices or beneath boulders, other grazers were scarce, and kelps colonized the bottom to $10-\mathrm{m}$ depths. The algal communities in these areas appeared to be simple downward extensions of sublittoral fringe communities. Where sea otters had not fed, kelps were limited to shallow water by abundant sea urchins. The observed differences between the 2 types of areas are concluded to have been caused by early elimination of sea urchins by sea otters, as reported in Alaska and California. From the pattern of sea urchin abundance in the general area of the transplant, we were able to delineate the feeding range of this small population of sea otters.
\end{abstract}

\section{INTRODUCTION}

The sea otter Enhydra lutris once was abundant along the outer coast of British Columbia, Canada. It was hunted intensely after Cook's third voyage of exploration touched at Nootka Sound in 1778. By 1900 it was scarce (Moon, 1978), and the last confirmed record of a live specimen was made in 1929 (Cowan and Guiguet, 1965).

The sea otter is a voracious predator of sea urchins and other invertebrates (Kenyon, 1969). By reducing the number of sea urchins, sea otters promote the growth of kelp beds, and this in turn may affect populations of other invertebrates, fishes, and predators of fish. Those Aleutian Islands with sea otter populations have low numbers of sea urchins Strongylocentrotus polyacanthus, which are small and restricted to crevices or deep water (Estes and Palmisano, 1974; Estes et al., 1978). Aleutian Islands without sea otter popula-

\footnotetext{
- Priority of authorship is alphabetical
}

tions have numerous sea urchins which are large, found in exposed areas, and in shallow water. At islands without sea otters, sea urchin grazing prevents the development of subtidal macrophytes, but where sea otters are present kelp associations grow to depths of $24 \mathrm{~m}$ below mean lower low water (MLLW). These authors document differences in invertebrate population structure and in kelp, fish, and harbour seal abundance; all appear to be brought about indirectly by the activities of sea otters (Simenstad et al., 1978).

In California, the expanding sea otter population has had a similar impact on the sea urchins Strongylocentrotus franciscanus and S. purpuratus. McLean (1962) and Ebert (1968) reported substantial decreases in sea urchin abundance after migration of sea otters into new feeding areas. In an area occupied by sea otters since the early 1960's, Lowry and Pearse (1973) found that both sea urchins and abalone Haliotis spp. were small, reduced in abundance from previous levels, and restricted to crevices. Cooper et al. (1977) repeated the observations on abalone, and reported that abalone 
size and abundance remained low. Since abalone are important to both commercial and recreational harvests, changes in abalone abundance caused by sea otters present an important and controversial problem (Bissell and Hubbard, 1968; Cicin-Sain et al., 1977).

Sea otters were re-introduced into British Columbia in 3 separate transplants from 1969 to 1972 (Bigg and MacAskie, 1978). A total of 89 individuals were moved from Amchitka Island and Prince William Sound, Alaska, to the Bunsby Islands (Fig. 1) near Kyuquot. In 1977 an aerial survey (Bigg and MacAskie, 1978) showed a population of 55 individuals remaining in the area, and a separate colony of 15 individuals near Nootka Sound. A 1978 survey confirmed these numbers (Michael Bigg and Graeme Ellis; pers. comm.). Later surveys have yielded confusing results, and population trends are not clear.

Sea otters observed in the Bunsby Islands group during the summer of 1978 (Morris et al., 1981) fed mostly on unidentified clams, and also on red and purple sea urchins Strongylocentrotus franciscanus and $S$. purpuratus. The red sea urchin limits the vertical distribution of kelp on the outer British Columbia coast (Low, 1975; Pace, 1975; Druehl, 1978; Breen, 1980), and large shallow subtidal areas are devoid of erect fleshy macrophytes. Lawrence (1975) terms such areas "barren grounds", and documents their world- wide extent. In British Columbia the obvious inference is that sea urchins now are more numerous, and that kelps correspondingly are more restricted in their vertical range than they were before sea otters were hunted to extinction.

There were 2 objects to the observations made during the current study. First, sea otter feeding areas were compared with nearby areas without sea otters to determine the ecological effect of foraging. Second, observations were made in the area adjacent to the known range of the Bunsby population to delineate the total feeding range. This has immediate importance in obtaining ecological reserve status for the area for the protection of its re-introduced sea otter population.

\section{STUDY SITE AND METHODS}

The sea otters released within the Bunsby Islands subsequently have been observed at the southernmost edge of the Bunsby Island group, at the Clara Islet complex of rocks, at Gull Islet, and at the Farout Rocks (Fig. 1) (Morris et al., 1981; our observations). Within these areas there is a wide range of wave exposure conditions. The inshore area among the Bunsby Islands is very sheltered and supports soft bottom communities; the Farout Rocks are exposed directly to

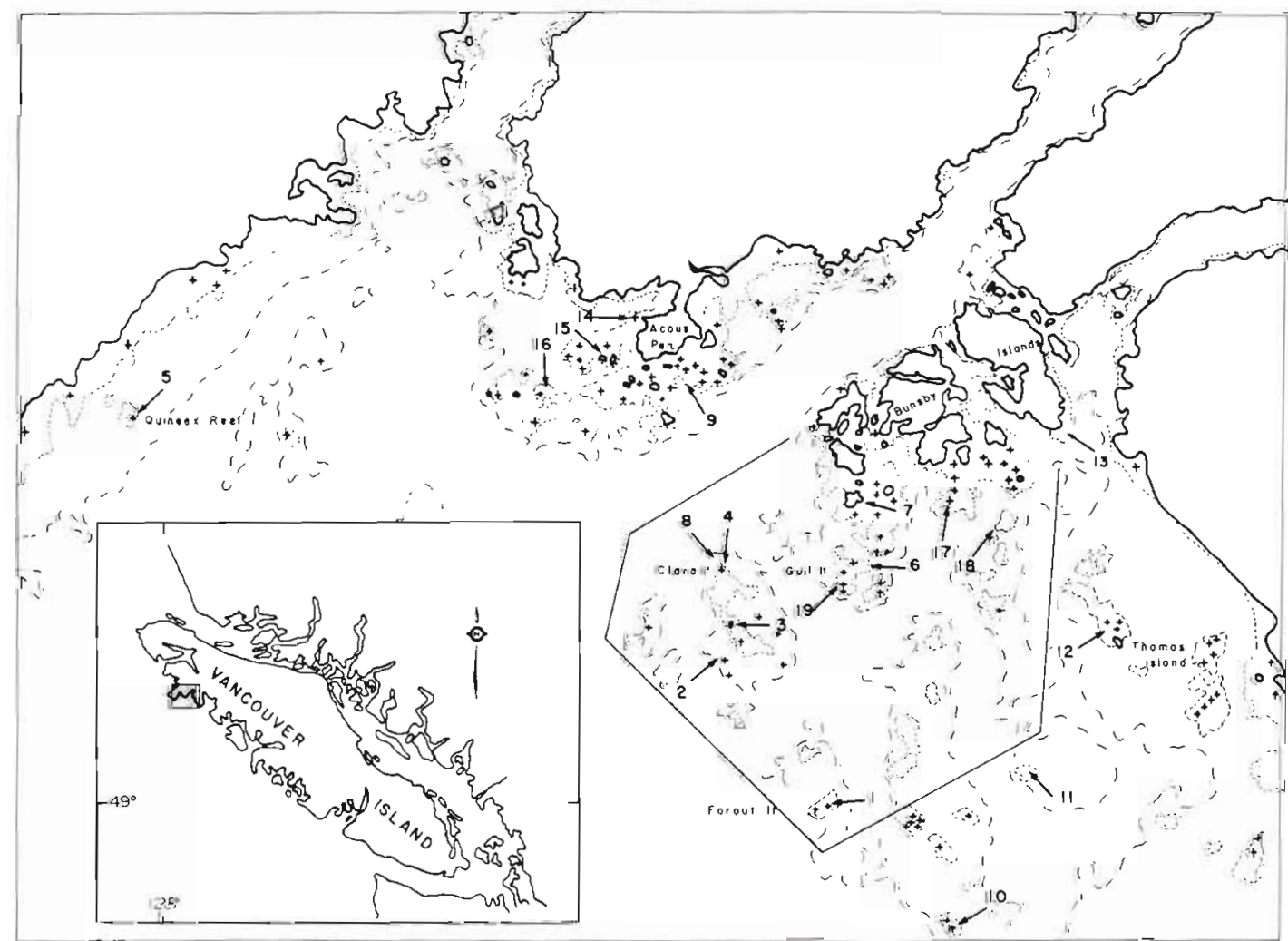

Fig. 1. Area of British Columbia sea otter transplant. Depth contours shown at 5 and 20 fathoms $(9.1$ and $36.6 \mathrm{~m})$. Crosses: rocks; solid straight lines: sea otter feeding range determined in this study; numbers: study sites 
oceanic swells. The complex of reefs and rocks frequented by the seá otters is formed by solid, jagged rock masses projecting through a flat sand or shell bottom. The reefs vary considerably in individual depth and topography.

During the period September 21-24, 1979, underwater observations were made with SCUBA at the 19 sites shown in Fig. 1. At each site (Table 1), 2 divers recorded or estimated visually (1) substrate type and slope at various depths; (2) algal species dominating the overhead canopy, the understory, the turf and on the rock itself; (3) percent cover of dominant algal species; (4) depths at which major algal changes occurred; (5) density and size ranges of red sea urchins and abalone; (6) density or percent cover of the most abundant invertebrates; and (7) presence of abundant fishes identified visually. Algal species were collected and preserved for further identification.

Depths were read from divers depth gauges; later, these were corrected from tide tables to provide depths below chart datum - at this location $0.77 \mathrm{~m}$ below MLLW. Depths reported here are given as meters below chart datum unless otherwise indicated. Because of the strong surge at most sites, the intertidal zone could not always be examined systematically.

Notes also were made on the location and number of sea otters seen during diving trips. No formal attempt was made to obtain systematic counts of the sea otters in the area as a whole - a proper count can be made only from the air - or to establish from sightings where the sea otters were feeding, as this had been done extensively the previous summer.

\section{RESULTS}

A summary of observations is presented in Table 1 detailed observations in Stewart et al. (1981).

\section{Sea Otter Observations}

Several groups of sea otters were seen in the areas listed by Morris et al. (1981). One group contained at least 11 individuals, other groups were smaller. The animals were retiring and could not be approached closer than $50 \mathrm{~m}$.

\section{Subtidal Observations}

Our observations are divided into 3 groups based on site use: known sea otter feeding sites; sites where sea otters have not been seen and presumably had not fed; and sites where it was not known whether sea otters had fed.

\section{Known Sea Otter Feeding Sites}

At 7 locations (Table 1, Sites 1-4, 6, 8 and 19) where sea otter feeding had been observed, red sea urchins were extremely scarce. Less than 12 were seen at 6 of these sites, mostly in crevices or under overhangs. At the remaining site sea urchin density reached 2 ind. $\mathrm{m}^{-2}$, but all sea urchins were in deep fissures or under boulders in relatively deep water $(10-15 \mathrm{~m})$. Sea urchins seen under boulders ranged to an estimated $150 \mathrm{~mm}$ in test diameter, but all those seen in crevices were less than $100 \mathrm{~mm}$.

Kelp was extensive at these feeding sites, and the increased biomass was apparent even from an aircraft. The dominant major algal species and their distribution were similar at all 7 sites. In every case Nereocystis luetkeana formed a dense surface canopy, and the understory contained Pterygophora californica, Laminaria setchellii, Laminaria spp., or a mixture of these species. These algae occurred from shallow water, usually below a band of the basket grass Phyllospadix scouleri near datum, to deeper water. Their lower limit occurred either where the bottom changed to shell or at 7-10-m depths.

There was a characteristic dense turf of bladed red algae underneath the kelps. The most abundant and consistent species were Constantinea subulifera and C. simplex (forming 10-75\% cover), Gigartina spp., Botryoglossum farlowianum, Opuntiella californica, Iridaea spp. and Laurencia spectabilis. Large quantities of algal drift and detritus were found trapped in crevices and depressions.

Cover of the rock surface itself was variable. Foliose coralline algae and Codium setchellii often were important but equally often absent. At some sites, large barnacles Balanus nubilus covered much of the primary space, and were being eaten by dense aggregations of the sea star Pisaster ochraceus. Along with these barnacles, the rock surface was richly encrusted with bryozoans, hydroids, sponges, colonial ascidians, tunicates (especially Styela montereyensis) and sea anemones (especially Metridium senile, Tealia piscivora, $T$. crassicornis and Epiactis prolifera).

Abalone (Haliotis kamtschatkana) were abundant only at 1 site, where all were under rocks in broad fissures. At the 6 remaining sites, no more than 18 abalone were seen in all. Only 1 abalone over $100 \mathrm{~mm}$ in length was seen; the remainder ranged from 20-80 mm

Potential food items for sea otters seemed scarce. In the 7 feeding sites, we saw only 1 red turban snail Astraea gibberosa and one sea mussel Mytilus californianus, although the latter were numerous in the intertidal zone at these sites. No more than 6 keyhole limpets Diodora aspera, rock scallops Hinnites gigan- 


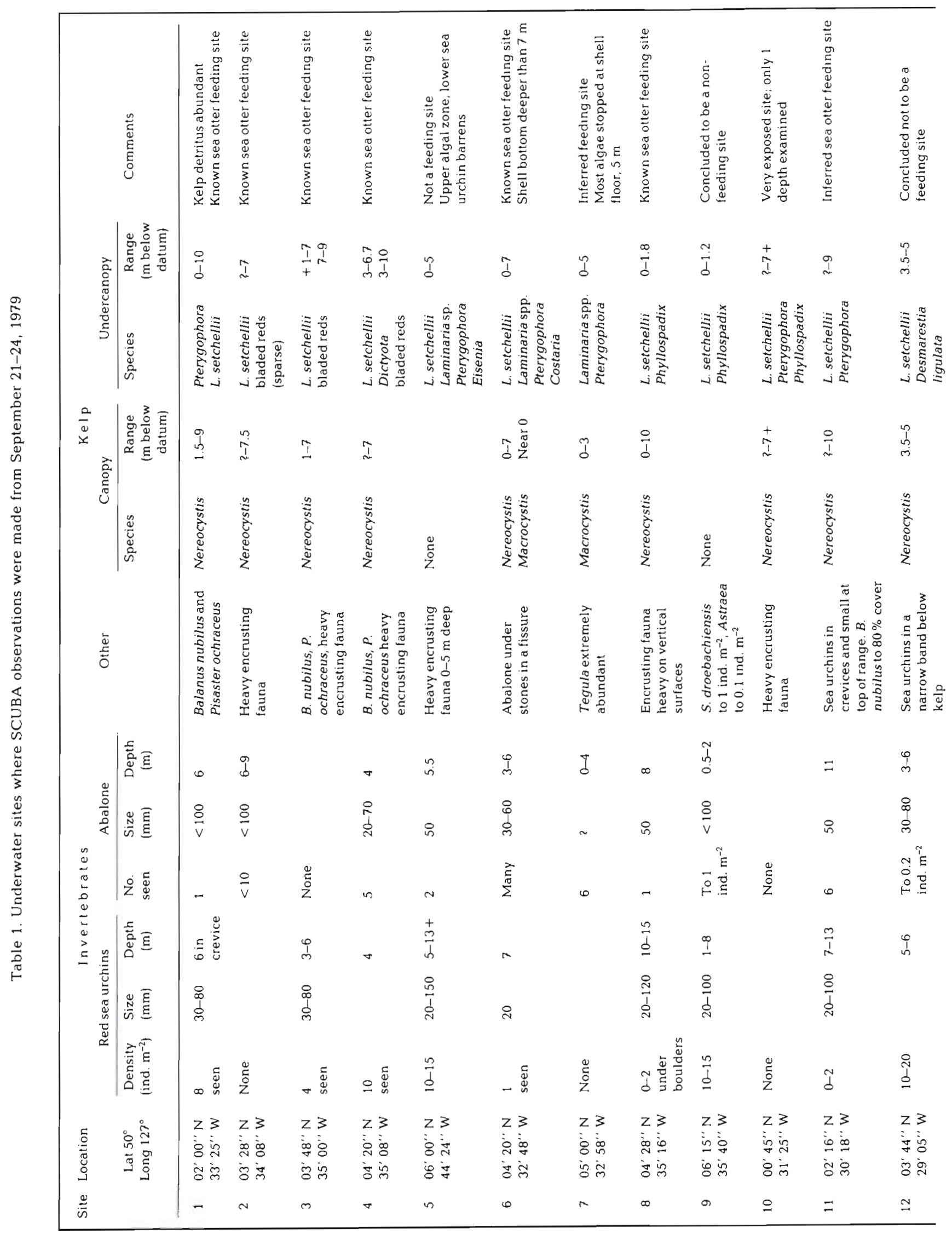




\begin{tabular}{|c|c|c|c|c|c|c|}
\hline 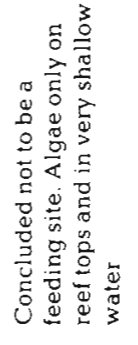 & 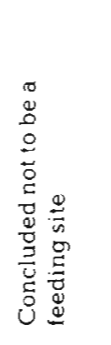 & 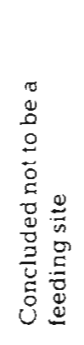 & 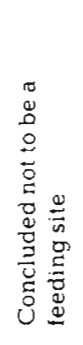 & 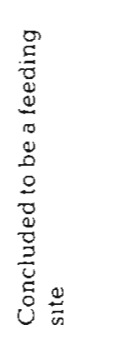 & 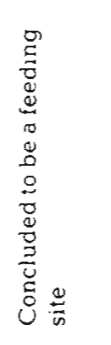 & 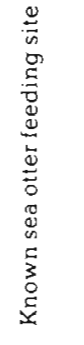 \\
\hline$\frac{1}{+}$ & $\begin{array}{l}n \\
0 \\
y \\
0 \\
m \\
m\end{array}$ & & $\tilde{d}$ & $\begin{array}{l}0 \\
1 \\
0\end{array}$ & & $\stackrel{i}{i}$ \\
\hline 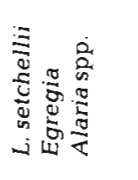 & 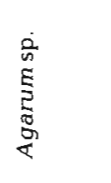 & 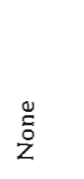 & 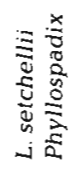 & 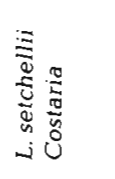 & $\begin{array}{l}\stackrel{\Xi}{0} \\
\stackrel{2}{Z}\end{array}$ & 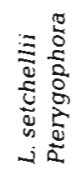 \\
\hline & 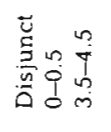 & 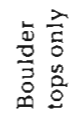 & 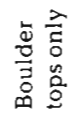 & in & $\begin{array}{l}\infty \\
1 \\
0\end{array}$ & $\begin{array}{l}\text { in } \\
\text { s. }\end{array}$ \\
\hline 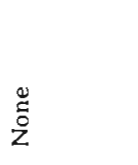 & 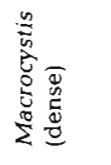 & 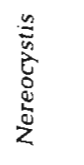 & 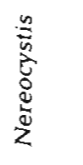 & 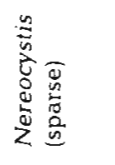 & 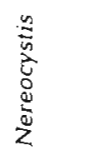 & 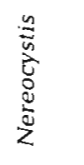 \\
\hline & & & & 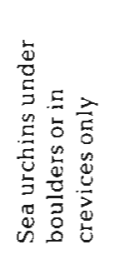 & 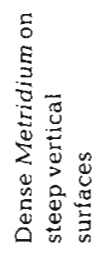 & 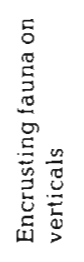 \\
\hline$\frac{?}{t}$ & & $\varphi$ & $\stackrel{\infty}{\sim}$ & & & $\stackrel{0}{m}$ \\
\hline 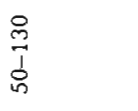 & & $\begin{array}{l}\text { m } \\
\stackrel{1}{1} \\
0 \\
i\end{array}$ & $\begin{array}{l}\mathscr{Q} \\
\dot{\sigma} \\
\dot{\sigma}\end{array}$ & & & $\begin{array}{l}0 \\
\vdots \\
0 \\
0\end{array}$ \\
\hline 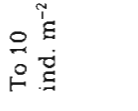 & $\begin{array}{l}\text { 巳̆ } \\
\text { Zे }\end{array}$ & 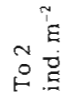 & 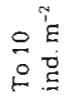 & 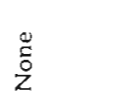 & $\begin{array}{l}\text { ğ } \\
\text { Zे }\end{array}$ & $\sim$ \\
\hline 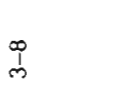 & $\begin{array}{c}n \\
\overrightarrow{1} \\
n \\
0 \\
0\end{array}$ & $?$ & $\stackrel{q}{i}$ & $\frac{\pi}{1}$ & & - \\
\hline & & & & & & $\stackrel{8}{ }$ \\
\hline !n & i & 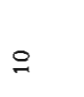 & $\stackrel{+}{g}$ & $\vec{v}$ & $\begin{array}{l}\stackrel{\Perp}{0} \\
Z\end{array}$ & - \\
\hline 23 & 23 & 23 & $z 3$ & 23 & 23 & $z 3$ \\
\hline 高 & 熔 & 商 & 言 & 产 & is & 率 \\
\hline in & \&: & 路 & 迤 & पे & पे & 这 \\
\hline$\stackrel{3}{a}$ & $\Xi$ & $\stackrel{2}{\sim}$ & $\stackrel{\circ}{\circ}$ & 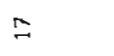 & $\stackrel{D}{2}$ & $\stackrel{9}{\square}$ \\
\hline
\end{tabular}

teus, green sea urchins Strongylocentrotus droebachiensis, or purple sea urchins were seen at any of these sites. Crabs were mostly anomurans, small and hidden. The small snails Ceratostoma foliatum, Amphissa columbiana, Collisella ochracea, and Acmaea mitra reached densities of $1-5$ ind. $\mathrm{m}^{-2}$ at all these sites. Tegula pulligo was very dense (up to 50 ind. $\mathrm{m}^{-2}$ ) in and near the kelp, and hermit crabs inhabiting Tegula shells reached even greater densities.

\section{Non-Feeding Sites}

From the observations made during the summer of 1978 (Morris et al., 1981), sea otters apparently had not fed at Sites 9,14, 15 and 16, nor did they range as far west as Site 5 .

The distribution and abundance of red sea urchins at each of these 5 sites was very different from the 7 sites just described. Estimated sea urchin density reached at least $5-10$ ind. $\mathrm{m}^{-2}$. Sea urchins were associated with distinct barren grounds with upper limits at $0.5-2.0 \mathrm{~m}$ (except that this boundary occurred at $5 \mathrm{~m}$ at the exposed Site 5). Most of these individuals were found concentrated on the open rock faces and boulder faces. At several sites the majority were greater than $100 \mathrm{~mm}$ in diameter. Green sea urchins Strongylocentrotus droebachiensis reached 4 ind. $\mathrm{m}^{-2}$ in the sublittoral fringe at 1 site, but were scarce elsewhere.

The dominant kelps at these sites were essentially the same species as in sea otter feeding areas, but their distribution was markedly different. Nereocystis was the canopy species at 3 sites, Laminaria setchellii was dominant in the undercanopy at all 5 sites, and Pterygophora and Eisenia arborea were present at 1 site.

At Sites 5, 9 and 14, kelp extended down to the top of the sea urchin zone, then stopped abruptly, and sea urchins continued into deeper water. At Sites 15 and 16, distribution of most kelps stopped where sea urchins began, but Nereocystis was found growing from the tops of high boulders in the otherwise barren areas dominated by sea urchins. At both places, sea urchins were found grazing on these plants.

Bladed red algae in the dense turf were again dominated by Gigartina spp., Botryoglossum farlowianum, Iridaea spp. and Constantinea spp. The rock surface under the kelps was covered with encrusting organisms, as described for the feeding areas, but large numbers of Balanus nubilus were not observed, and Pisaster ochraceus was restricted to the upper subtidal and intertidal zones.

Within the sea urchin barrens, encrusting fauna were not abundant except on vertical surfaces. Encrusting coralline algae (Lithothamnion and related 
genera) and the colonial polychaete Dodecaceria fewkesi dominated nearly all primary space. Chitons Tonicella lineata and limpets Acmaea mitra and Collisella ochracea were numerous in the barrens.

Abalone were scarce or absent at 2 sites, but reached densities of $1-10$ ind $m^{-2}$ at 3 sites. They were mostly exposed, and at 1 site reached $135 \mathrm{~mm}$ in length.

Astraea was noted in densities up to 0.5 ind. $\mathrm{m}^{-2}$ at 2 sites. No further invertebrate species was obviously greater in abundance at non-feeding than at feeding sites. Tegula was much less abundant at these nonfeeding sites, and was found only in association with kelps.

\section{Other Sites}

At Sites 7, 10-13,17 and 18, we had no information as to whether sea otters had fed there or not. Based on the observations just reported, we suggest that red sea urchin distribution is useful in determining whether or not sea otters have fed at a given site. At Site 7 , no sea urchins were seen, and dense Nereocystis and Laminaria covered the rocks to $5 \mathrm{~m}$, where a flat shell floor began. From the complete absence of sea urchins, we inferred that this site must have been foraged by sea otters. Site 10 comprised a group of boulders on a flat shell floor $7 \mathrm{~m}$ below datum. There were no sea urchins, but the effects of surge even at this depth $(8.5$ $m$ below the surface) were pronounced even on a calm day. The absence of sea urchins could be explained by the extreme exposure of the site to oceanic swells.

At Site 11, red sea urchins were present at 7 m the shallowest part of the reef examined) but were rare and restricted to crevices. They became more exposed and numerous with increasing depth. At $13 \mathrm{~m}$ they reached local densities of 2 ind. $m^{-2}$, but were distributed very irregularly. Nereocystis extended to $10 \mathrm{~m}$ as in sea otter feeding areas. We found 1 broken test, with irregular edges, that may have been broken by a sea otter. We considered this to be a sea otter feeding site.

Site 12 clearly was not a place where sea otters had fed. Nereocystis extended only to $5 \mathrm{~m}$, and red sea urchins were abundant both within the kelp and below it. Site 13 also was not a feeding site. It was dominated by sea urchins below $2 \mathrm{~m}$, and kelps were restricted to the upper subtidal zone. Abalone were abundant from $0.5 \mathrm{~m}$ above datum to $5-\mathrm{m}$ depths. This was 1 of only 3 sites at which abalone greater than $100 \mathrm{~mm}$ in length were found.

At Site 17, red sea urchins were present at low densities at depths of 6-12 m, allowing only sparse canopy species to grow there. They were found only under boulders and in crevices, however, indicating that sea otters may have fed there. The complete ab- sence of sea urchins at Site 18, where kelps extended to $6-8 \mathrm{~m}$, indicated that sea otters had probably fed there.

\section{Further Observations}

Our notes on fishes were not systematic enough to permit a comparison of feeding and non-feeding areas. We noted large schools of black rockfish Sebastes melanops and juvenile rockfish Sebastes sp. or spp. in the kelp at sea otter feeding sites and at Site 13.

\section{DISCUSSION}

The pattern of these observations is consistent with what is known of the ecology of sea otters, sea urchins and kelps in other parts of the northeast Pacific Ocean. Where sea otters are known to feed, sea urchins are rare and algae are extensive. Elsewhere, red sea urchins dominate the subtidal zone except for a shallow fringe to which kelps are restricted.

Observations were made in the Bunsby Island area by fishermen before the inital 1969 transplant (Kayra, pers. comm.), and in 1972 in association with the last transplant (Miller, unpubl., cited by Stewart et al., 1981; Quayle, pers. comm.). These cources are consistent in reporting that red sea urchins at Clara and Gull islets, and on the southern edge of the Bunsby Islands, were dense and were obvious when viewed from the surface, and kelp correspondingly was restricted to shallow water. From this previous evidence, it seems certain that the current absence of sea urchins has resulted from sea otter predation. Abalone and Astraea were also present in lower numbers and smaller sizes where sea otters had fed

In the absence of sea otters, the role of red sea urchins in preventing the downward extension of kelps has been well documented by experimental removals and descriptive observation (Low, 1975; Pace, 1975; Druehl, 1978). The boundary between deeper sea urchins and shallower kelps is essentially stable but varies in depth from place to place. Depth of the boundary is determined by factors associated with water mixing and movement, substrate type, and slope (Pace, 1975; Breen, 1980). Since the local extinction of sea otters, kelp has existed in shallow refuges whose size is determined by local hydrography and topography.

Other authors have reported 2 kinds of change in algal communities following the removal or disappearance of sea urchins. First, communities may experience succession in which annual species are replaced by competitively stronger perennials, usually Laminaria 
(Vadas, 1968; Dayton, 1975; Foreman, 1977; Duggins, 1980). Second, there may be decreased abundance of competitively weaker species such as Agarum and Desmarestia, which had previously been maintained by selective sea urchin grazing (Vadas, 1968; Irvine, 1973). On the basis of these results, we would not have expected the dense Nereocystis canopies that were observed in sea otter feeding areas where sea urchins were absent. In the studies just cited, Nereocystis was found to be a temporary successional form which was replaced by Laminaria in the absence of grazing (Vadas, 1968; Foreman, 1977; Duggins, 1980) The existence of thick Nereocystis canopies in areas inhabited by sea otters for several years is thus unexpected. It may indicate that these communities are strongly influenced by regular physical disturbance, such as oceanic surge, that interrupts competition

The feeding range of the Bunsby Island sea otter population is readily identifiable by the near-absence of red sea urchins. Although deficient in sea urchins, the area still provides clams as prey for sea otters (Morris et al., 1981); it also contains less preferred items such as Tegula and sea mussels, which apparently have not yet been exploited. The present feeding range (Fig. 1) appears to be approximately $26 \mathrm{~km}^{2}$, although part of this area may be too deep for sea otters to exploit. Sea otter density therefore is approximately 2 individuals $\mathrm{km}^{-2}$. The density of sea otters at carrying capacity of the habitat is reported to be 4-30 ind. $\mathrm{km}^{-2}$ (respectively Kenyon, 1969; Estes et al., 1978). Loughlin (1980) found that California sea otters occupied territories averaging 56 ha, corresponding to 1.8 ind. $\mathrm{km}^{-2}$ at saturation. Thus the present B. C. population may be near carrying capacity of the area it occupies, although a large surrounding area of suitable habitat remains unexploited.

In November 1977 an Ecological Reserve was proposed in Checleset Bay for protection of sea otter habitat (Krajina et al., 1978). The area of the proposed reserve is approximately 10 times the feeding range inferred from this study of the current sea otter population. We conclude that the proposed reserve area should provide ample space for future population expansion.

Acknowledgements. We are grateful to Esko Kayra and his family for their help and advice and to the numerous individuals who provided information and criticized the manuscript.

\section{LITERATURE CITED}

Bigg, M. A., MacAskie, I. B. (1978). Sea otters re-established in British Columbia. J. Mammal. 59 (4): 874-876

Bissell, H., Hubbard, F. (1968). Report on the sea otter, abalone and kelp resources in San Luis Obispo and Monterey Counties and proposals for reducing the conflict between the commercial abalone industry and the sea otter Mimeo report to the California Senate. California Fish and Game, Sacramento, California

Breen, P. A. (1980). The ecology of red sea urchins in British Columbia. In: Proceedings of the international symposium on coastal Pacific marine life. Western Washington University, Bellingham, pp. 3-12

Cicin-Sain, B., Moore, J. E., Wyner, A. J. (1977). Management approaches for marine fisheries: the case of the California abalone. University of California Sea Grant Program, Sea Grant Publication 54: 1-223

Cooper, J., Wieland, M., Hines, A. (1977). Subtidal abalone populations in an area inhabited by sea otters. Veliger 20 (2): 163-167

Cowan, I. McT., Guiguet, C. J. (1965). The mammals of British Columbia, 3rd ed. (rev.). British Columbia Provincial Museum, Victoria

Dayton, P. K. (1975). Experimental studies of algal canopy interactions in a sea otter-dominated kelp community at Amchitka Island, Alaska. Fish. Bull. U. S. 73 (2): 230-237

Druehl, L. D. (1978). The distribution of Macrocystis integrifolia in British Columbia as related to some environmental parameters. Can. J. Bot. 56 (1): 69-79

Duggins, D. O. (1980). Kelp beds and sea otters: an experimental approach. Ecology 61 (3): 447-453

Ebert, E. E. (1968). A food habits study of the southern sea otter, Enhydra lutris nereis. Calif. Fish Game 54 (1): 33-42

Estes, J. A., Palmisano, J. F. (1974). Sea otters: their role in structuring nearshore communities. Science, N. Y 185: $1058-1060$

Estes, J. A., Smith, N. S., Palmisano, J. F. (1978). Sea otter predation and community organization in the western Aleutian Islands, Alaska. Ecology 59 (4): 822-833

Foreman, R. E. (1977). Benthic community modification and recovery following intensive grazing by Stronglocentrotus droebachiensis. Helgoländer wiss. Meeresunters. 30: $468-484$

Irvine, G. V (1973). The effect of selective feeding by two species of sea urchins on the structuring of algal communities. M. S. thesis, University of Washington, Seattle

Kenyon, K. W. (1969). The sea otter in the eastern Pacific Ocean. U. S. Dept. of the Interior, Bureau Sport Fisheries and Wildlife. North American Fauna 68: 1-352 (Dover Publications, New York, 1975)

Krajina, V J., Foster, J. B., Pojar, J., Carson, T A. (1978). Ecological reserves in B. C., Queen's Printer, Victoria

Lawrence, J M. (1975). On the relationships between marine plants and sea urchins. Oceanogr mar. Biol. A. Rev. 13: 213-286

Loughlin, T. R. (1980). Home range and territoriality of sea otters near Monterey, California. J, Wildl. Mgmt. 44 (3): $576-582$

Low, C. J. (1975). The effect of grouping in Strongylocentrotus franciscanus, the giant red sea urchin, on its population biology. Ph. D. thesis, University of British Columbia, Vancouver

Lowry, L. F., Pearse, J. F. (1973). Abalones and sea urchins in an area inhabited by sea otters. Mar Biol. 23: 213-219

McLean, J. H. (1962). Sublittoral ecology of kelp beds of the open coast near Carmel, California. Biol. Bull. mar. biol. Lab., Woods Hole 122: 95-114

Moon, B. J. (1978). Vanished companions: the changing relationship of the west coast people to the animal world. Sound Heritage 7 (1): 71-77 (Provincial Archives of British Columbia, Victoria)

Morris, R. L., Ellis, D. V., Emerson, B. P. (1981). The British Columbia transplant of sea otters (Enhydra lutris). Biol Cons. 20: 291-295 
Pace, D. R. (1975). Environmental control of red sea urchin (Strongylocentrotus franciscanus) vertical distribution in Barkley Sound, British Columbia, Ph. D. thesis, Simon Fraser University, Burnaby

Simenstad, C. A., Estes, J. A., Kenyon, K. W. (1978). Aleuts, sea otters and alternate stable-state communities. Science, N. Y. 200: 403-411
Stewart, E. A., Foster, J. B., Carson, T. A., Breen, P. A. (1981) Observations of sea urchins, other invertebrates and algae in an area inhabited by sea otters. Can. Aquat. Sci. Data Rep. Ser.

Vadas, R. L. (1968). The ecology of Agarum and the kelp bed community. Ph. D. thesis, University of Washington, Seattle

This paper was presented by Dr. D. Alderdice; it was accepted for printing on August 30,1981 